Klaudia Máté-Bella - Ildikó Ritzl-Kazimir

\title{
Analysis of the Hungarian insurance sector's gross value added from 2003 to 2017
}

\author{
KLAUdiA MÁTÉ-BELla \\ Chief Councillor \\ Hungarian Central Statistical Office, \\ Hungary \\ Email: klaudia.bella@ksh.hu
}

\author{
ILDIKÓ RITZL-KAZIMIR \\ Chief Councillor \\ Hungarian Central Statistical Office, \\ Hungary \\ Email: ildiko.ritzlne@ksh.hu
}

Hungarian insurance companies are most often analysed for profitability, market share, premiums and expenses, or from the perspective of prudential issues. There has, however, been little discussion concerning the factors related to the gross value added by the sector to the country's economy. Calculation of the gross value added is regulated by the European System of Accounts, 2010, and the applied calculation method is presented in the Hungarian Gross National Income Inventory. This study examines whether premiums and claims costs are appropriate proxies to capture the patterns of gross value added by insurance companies. Using a time series analysis, the authors examine the relationship between the total annual gross value added and several aggregated accounting figures from Hungarian insurance companies. Their analysis and tests show that premiums and claims costs are good proxies of gross value added only for the period 2006-2013. It is also found that the ratio of intermediate consumption to output varied across a relatively wide range during this period, which had a significant impact on the gross value added by the insurance sector. Because this ratio is determined by several factors - such as premiums, claims costs, change in technical and actuarial reserves, and the cost of contracted services - each separate factor is not a good proxy in the long term, but they may be suitable in the short term.

KEYWORDS: gross value added, insurance sector, econometric model

The Hungarian insurance industry has undergone many changes in recent years. Several processes have affected the insurance companies' economic activity. For example, Hungary's accession to the EU (European Union) in 2004 led to the harmonisation of insurance legislation. The life insurance business was adversely affected by several tax allowance changes as well as the financial crisis of 2008. Only in recent years did this sector begin to grow, mainly due to an increase in the number 
of pension insurance policies; however, the total number of contracts still did not reach the same level as its peak in 2004. The non-life insurance business has experienced other processes. The continuous harmonisation with the latest EU motor insurance directive has set the legal framework. The change in the number of vehicles on the road has also had an impact on the premiums and claims costs relating to compulsory third-party liability vehicle insurance. In particular, the number of new vehicles registered for the first time in Hungary, contributed to the growth of the non-life insurance business before 2004 and after 2014.

The gross value added by the insurance industry to Hungary's total economic output is calculated according to ESA 2010 (European System of Accounts; Official Journal of European Union [2013]) and the detailed calculation method is presented in the Hungarian GNI (gross national income) Inventory (HCSO [2011]). This study analyses the processes in the insurance industry, which is based upon the EU's NACE Rev. 2 (Nomenclature statistique des activités économiques dans la Communauté européenne - Statistical Classification of Economic Activities in the European Community; Eurostat [2008]) Division 65 (Insurance, reinsurance, and pension funding, except compulsory social security; hereinafter referred to as NACE 65 Rev. 2) codes in the Hungarian national accounts. Even though the insurance industry also includes pension and health insurance funds, we examine only the effects of the life and non-life insurance subsectors on the gross value added.

To understand the processes and methods, we address the following research questions: "Are »premiums « and »claims costs « suitable proxies to capture the patterns of gross value added by insurance companies?' 'If not or only partly suitable, which other factors influence the gross value added?'

The aim of this study is not to forecast the gross value added by insurance activity, but to understand and present the special nature of this industry coming from its special products, services, and accounting rules. To fulfil this research goal, we compiled various econometric models to analyse the relationships between variables during the period 2003-2017.

\section{Literature review}

The Hungarian insurance industry changed significantly during the study period. In the next sub-sections, we first explain the most important processes in the sector and provide a literature review related to these changes (including the ones in the legal environment, which could affect the economic activity of insurance companies). Second, the regulations specified in ESA 2010 and the calculation method regarding the gross value added by insurance companies are presented.

HUNGARIAN STATISTICAL REVIEW, VOLUME 2, NuMBER 2, PP. 79-105. DOI: 10.35618/hsr2019.02.en079 


\subsection{The insurance industry in a macroeconomic context}

Insurance companies are unique enterprises. Their activities are based on risk sharing and the services they provide protect consumers against negative financial consequences of uncertain events (Official Journal of European Union [2013] 16.01 p. 383.). The services of insurance companies are also unique because their demand is strongly related to economic growth, the quality of the legal system, and the protection of property rights (Avram-Nguyen-Skully [2010]). Therefore, investments in emerging countries with high growth potential may be very desirable from the perspective of international mergers and contract acquisition transactions. The market liberalisation in the insurance industry has been an ongoing process since the 1990s. This process also promoted international mergers and contract acquisitions (FocarelliPozzolo [2008]).

Eling and Luhnen [2008] found that after the European single market came into effect, the insurance industry in Germany quickly adapted to the new conditions. One of the most obvious consequences of deregulation was the vigorous competition for market share using reduced premiums and steep discounts, which was concentrated in insurance subsectors with short contract lengths. Mahlberg and Url [2010] state that firms attempted more aggressive investment strategies by shifting their portfolios into high-yield asset classes in the 1990s. However, in 2001, share prices started becoming unfavourable and several natural and man-made catastrophes made this strategy unsustainable. This business environment put pressure on insurance companies to improve their underwriting business, either by improving their risk exposure or by cutting costs.

Based on the penetration rate of both life and non-life insurance (penetration rate is measured as the ratio of premiums in a year to the GDP [gross domestic product]), there are a few differences between developed and developing countries. The penetration rate of life insurance is significantly higher in developed countries in Europe, while the rate of non-life insurance is higher in less developed European countries (29 European countries were analysed in two groups, one consisted of the EU15, Norway, Switzerland, and Iceland and the other were made up of Central and Eastern European/NMS [new member states] countries, Turkey, and Croatia). Insurance has an impact on economic growth through investments and risk sharing. In developed countries, the effect is long-term due to the high life insurance penetration. In less developed countries, there is a more short-term effect because of the high ratio of non-life insurance (Haiss-Sümegi [2008]).

Methods for measuring economic performance in the financial sector - especially in the insurance sector - are also unique. According to Triplett and Bosworth [2004], the output of the finance and insurance industries is highly heterogeneous, making it harder to measure than, for example, the automobile or computer industries. It is

Hungarian StatisticAl REVIEW, VOLUME 2, NuMBER 2, PP. 79-105. DOI: 10.35618/hsr2019.02.en079 
agreed 'that the number of insurance policies is the analog to the "number of computers«, that the premium for a risk-adjusted insurance policy is the analog to the "price of a constant-performance computer«, and that the premium revenue of an insurance company corresponds to the $»$ sales (value of shipments) of a computer producer «' (Triplett-Bosworth [2004] p. 3.).

In the 1968 version of the SNA (System of National Accounts) (SNA68; United Nations Statistics Division [1968]), net premiums were used as a measure of the insurance industry's output, which is like the past United States' practice. This regulation caused insurance output in many countries to become negative and in some periods, insurance companies paid out more in claims than what they received in premiums. The 1993 version of the SNA (Commission of the EC-IMF-OECD-UNWorld Bank [1993]) modified the industry output by adding insurance company investment income to the previous output definition of premiums minus claims.

Triplett and Bosworth [2004] also do not agree with the 'premiums-minus-claims' definition of insurance output, based on their empirical estimates. They investigated the productivity growth from 1987 to 2001 in the United States using data from the Bureau of Economic Analysis industry accounts (based on the SNA68 method) and found that the insurance carrier and the insurance agent industries had negative measure multifactor productivity for most of that period. They argue that the measurement concept based on a 'risk-pooling' model is not correct. Instead, they favour the 'risk-assuming' model and propose that insurance company investment activities represent a secondary output that needs to be included in the measure of the insurance industry output, because the factors in the insurance industry are like any other joint products: both products are to be counted and both products need a price index.

In the case of insurance, the output depends on both the premiums and the claims (adjusted claims should be included in the calculations in the case of non-life insurance). Burgess [2011] draws attention to the fact that the proxies - which are applied for short-term estimates of economic indicators - can result in distortions in the GDP growth through the growth rate of financial gross value added. For example, in insurance activities, the (weighted) numbers of policies are commonly used as an output proxy; however, according to the complexity of output calculation, statisticians should not have unreasonably high expectations of some of these proxy measures.

\subsection{Main developments in the Hungarian insurance market from 2003 to 2017}

The most frequently presented indicators of the insurance market are the number of contracts, the premiums, claims costs, and total (and contract acquisition) costs. In this sub-section, we first use these indicators to analyse the life insurance business

HUNGARIAN STATISTICAL REVIEW, VOLUME 2, NuMBER 2, PP. 79-105. DOI: 10.35618/hsr2019.02.en079 
and the most important changes in the regulations during the study period, after which we examine the non-life insurance business. We emphasize that the country's new Civil Code that affects insurance companies' activities in several ways, was accepted during the analysed period, in 2009, by Act CXX of 2009 on the Civil Code.

\subsubsection{Life insurance business}

Figure 1 shows that the life insurance business reached its peak in 2003, after which a continual downturn is observable. In 2004, many life-insurance policies expired. There was also a significant change in the tax environment of the insurance industry: the introduction of discount maximisation and phased income limit reduced the number of life insurance tax-allowance recipients. In $2004,20 \%$ of the premiums paid for life and pension insurance with a domestic insurer was tax deductible. Following the amendments in the Act C of 2000 on accounting, 192/2000. (XI. 24.) Government Decree on the accounting rules of insurers was also amended in that year, which made it possible to value investments at market value. Due to the unfavourable money market position, the valuation of impairment of the government securities portfolio was a key issue that could affect the technical and actuarial reserves. (MABISZ [2005] pp. 8-9.)

Figure 1. Policies of insurance companies (number of contracts) at the end of the year

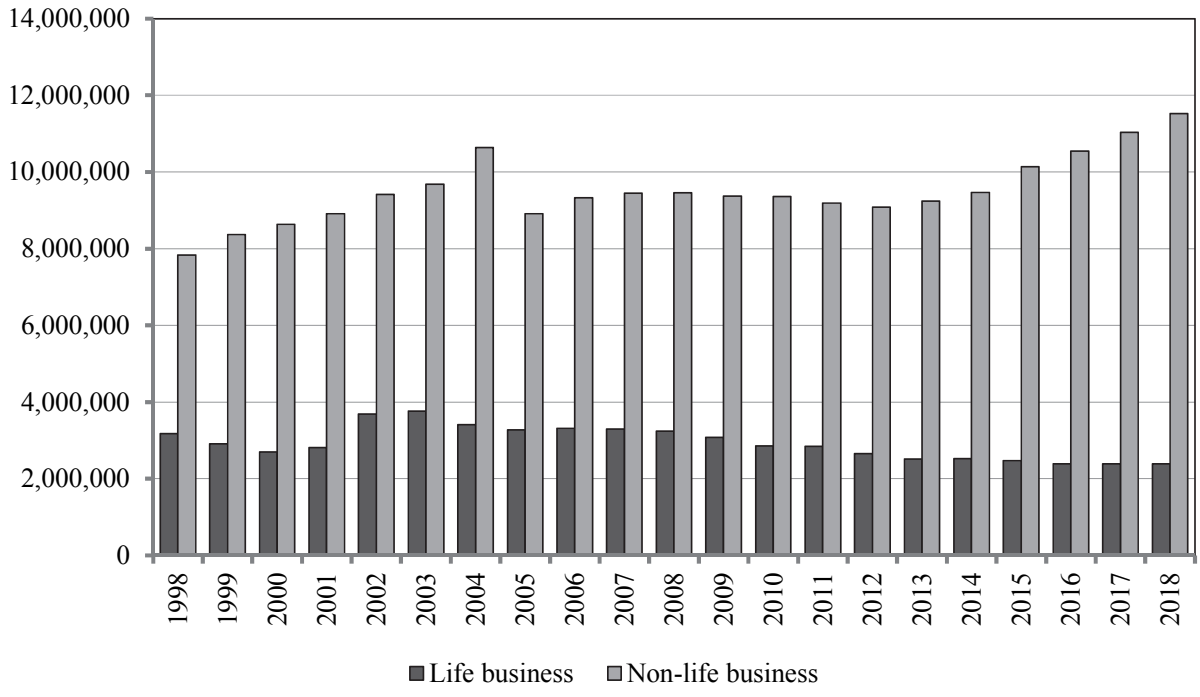

Note. Here and in the following figures as well as in Tables 12 and 13, we present periods longer than our study period to ease the understanding of the processes taken place in the Hungarian insurance market.

Source: Own calculation based on data of the Central Bank of Hungary (hereinafter MNB).

HUNGARIAN STATISTICAL REVIEW, VOLUME 2, NUMBER 2, PP. 79-105. DOI: 10.35618/hsr2019.02.en079 
In 2006, the upper income limit for eligibility for life insurance personal income tax allowance was reduced to HUF 3,400,000. On 1 September 2006, the interest tax rate changed. Provision of life insurance of at least 10-year maturity and pension insurance of at least three-year maturity continued to be exempt from interest tax. Thus, life insurance as a means of long-term savings gained a further tax advantage over other 'traditional' forms of savings. Unit-linked life insurance policies made on or before 31 August 2006, were also exempt from the new public burden. (MABISZ [2007] pp. 8-9.)

As the global financial crisis gradually spread to the economy, growth rates slowed down and business expectations deteriorated, which had a major impact on the development of the Hungarian economy from 2008 to 2012. In 2008, the gross financial savings of households fell by $11 \%$, while their financial liabilities increased by $3.8 \%$. As a result, the structure of household savings has been reorganized. It was generated, on the one hand, by the various degrees of devaluation of individual savings, and, on the other hand, by caution concerning riskier financial investments. Contrary to the previous trend, the proportion of investment certificates, insurance and pension fund reserves and the ratio of shares listed on the stock exchange dropped significantly. In parallel with this process, the bank deposits began to grow again following a continuous decline observed since 2000 (driven also by high loan interest rates). Within the household loans, the share of loans denominated in foreign currencies increased, due to the revaluation loss arising from the weaker HUF exchange rate, among others. Repayments grew substantially in all currencies and HUF. The growth of insurance companies came to a halt. Premium revenues declined by $18 \%$ in the life insurance business, while they stagnated in the other business lines. Furthermore, the annual profit decreased by $8 \%$ compared with the previous year. (MABISZ [2009] pp. 5-6.)

In the period 2007-2014, contract acquisition costs and operating costs increased. Moreover, claims settlement costs increased, which was caused by the mass withdrawal of savings during the financial crisis, not least because of the possibility of converting foreign currency loans to HUF at the beginning of 2012.

The previous tax allowance scheme was abolished on 1 January 2010, one of the elements thereof being the life insurance tax allowance. From 2010, the legal regulations encourage long-term investments with a lower tax rate on the return of investment than the tax rate generally applied to business profit. According to Act CXVII of 1995 on personal income tax 67/B. $\S(5)$, the return and yield of investment, registered separately as a long-term investment, is taxed at $10 \%$, if the investment is kept for three years, while the return and yield is tax free, if the investment is kept for five years. Act CXVI of 2009 deteriorated further the competitive position of life insurance relative to other savings products as the life and pension insurance products were not listed among the preferred long-term investments in the bill submitted.

HUNGARIAN STATISTICAL REVIEW, VOLUME 2, NuMBER 2, PP. 79-105. DOI: 10.35618/hsr2019.02.en079 
After MABISZ (Association of Hungarian Insurers) drew the legislator's attention to this fact in order to have competition-neutral regulations, the provisions on life and pension insurance products were also added to the act in a proposed amendment. (MABISZ [2010] pp. 5-6.)

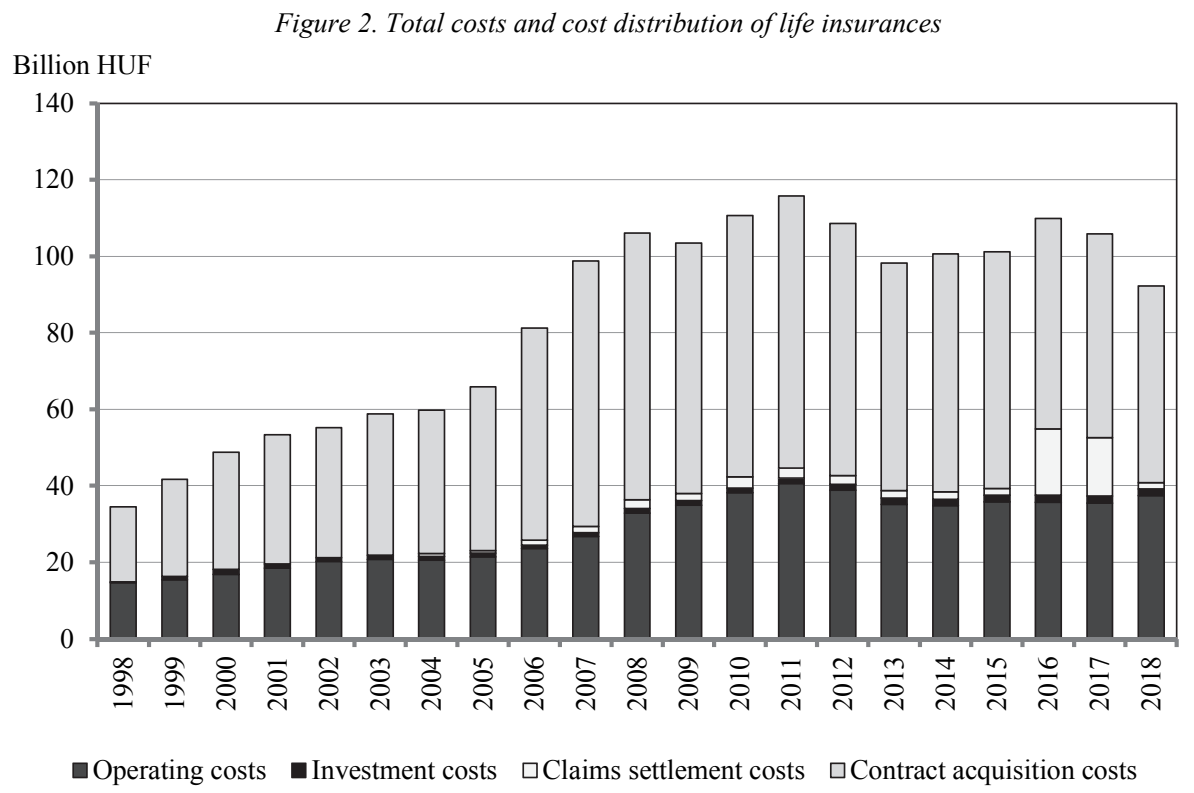

Source: Own calculation based on MNB data

In 2013, the total cost index of unit-linked life insurance products was introduced to provide transparency of costs and help clients comparing various products.

As a result of the harmonisation of tax allowance relating to long-term retirement self-care products, by the end of 2014 insurance companies managed more than 68,000 regular contracts eligible for personal income tax credit. Clients deposited a total of HUF 12.6 billion savings in these pension insurance policies. The annual average premium of pension insurance contracts exceeded HUF 220 thousand, meaning that customers increased their savings aimed for their retirements by almost HUF 20 thousand a month, on average. It was nearly one-third higher than the average premium of other savings-type regular life insurance products. (MABISZ [2015] pp. 4-7.)

Since 2014, the market has been driven by pension insurance. The favourable effect of insurance premiums is not only reflected in the increase in premium revenues, but it also outlines other positive trends. Of all stock, $21 \%$ already comes from this insurance product. The ratio of regular premium products has stabilized, $96.7 \%$ of

HUNGARIAN STATISTICAL REVIEW, VOLUME 2, NuMBER 2, PP. 79-105. DOI: 10.35618/hsr2019.02.en079 
the pension insurance contracts belong to that product. The expected retention period at the time of the contract has increased significantly (over 8 years), while the average contractual term for retirement insurance is 19.2 years. The average annual premium increased from HUF 184,662 in 2016 to HUF 206,004 in 2017, and the ratio of unit-linked and classical insurance policies has become stable (2/3-1/3). All the above shows that the introduction of a tax credit could effectively stimulate longterm savings. (MABISZ [2018] p. 17.)

\subsubsection{Non-life insurance business}

Compared with the life insurance business, the non-life insurance business shows a different trend over time. The number of contracts reached its peak in 2004 and in recent years it seems as if a new peak may be experienced, because the data of 2017 and 2018 show that the number of contracts exceeded that of 2004.

In 2004, a new insurance act, that is, Act LX of 2003 on insurers and insurance activity entered into force. The most important legislative changes were as follows: standard definition of certain concepts related to the EU member states, partial reregulation of the intermediary system, introduction of registration subject to qualifications, establishment of an institutional system related to Motor Insurance Directive No. 4, correction of investment regulations, restrictions in customer information rules, and re-regulation of the protection of business secrets and personal data. (MABISZ [2005] pp. 8-9.)

In 2007, several amendments to the Act LX of 2003 on insurers and insurance activity were passed. Act L of 2007 was the most significant among them, which was passed in mid-2007. It was necessitated in part by the transposition of EU Motor Insurance Directive No. 5. In accordance with two solvency directives passed in 2002, Act L of 2007 redefined the capital reserves prescribed for insurers: life insurance companies and non-life insurance companies providing liability insurance must have minimum capital reserves of EUR 3,200,000, and other non-life insurance companies must have EUR 2,200,000. The companies had to comply with these capital requirements by 1 January 2008. Act L of 2007 also clarified the definition of insurance intermediaries and - in certain areas - their record-keeping and training obligations. The range of information which insurance intermediaries must provide to customers was expanded, and at the proposal of the professional organisations, an official examination was introduced as a condition of registration.

As of 1 of January 2008, the maximum amount for personal injury claims reimbursable by the insurers changed: they were liable for damages of up to HUF 1,500 million per claim, irrespective of the number of injured parties. In the case of material damage, the per incident limit of HUF 500 million did not change. 
On 29 June 2009, Act LXII of 2009 on compulsory third-party liability vehicle insurance was promulgated and it entered into force on 1 January 2010 (MABISZ [2010] pp. 3-4.).

In 2010, Hungarian insurance companies paid out HUF 25 billion for weather damages due to the summer storms and floods (MABISZ [2011]). The extended financial crisis also affected adversely the non-life insurance market (particularly) in that year. The significant drop of premium revenues was mainly due to the continuous downward trend in the average compulsory third-party liability vehicle insurance premiums over the years, which was, in turn, due to strong competition and the improving claim ratio. However, there was another reason for the decline in premium revenues: the financial crisis also brought about a drop in new car sales, which of course led to fewer new compulsory insurance policy contracts. (MABISZ [2011] pp. 3-4.)

In the middle of 2011, the regulations applicable to the bonus-malus system changed. From the entry into force of the Decree 21/2011. (VI. 10.) of Ministry of National Economy, paper-based bonus-malus certificates will no longer be accepted for determining the rating of customers. Customer ratings can be done only on the basis of the data contained in the Claim History Registration System. (MABISZ [2013] p. 23.)

Another positive change was the new system that was introduced in 2012 to support farmers. In the same year, the twenty years of the regulation of the compulsory third-party liability vehicle insurance market, that is, the liberalisation process, which started in 1992, was completed. The compulsory third-party liability vehicle insurance tariffs can now be changed during the year, allowing insurers to quickly react to market processes (MABISZ [2013] pp. 4-7.). This results in better customised premiums to consumers and contributed to the ending of the gradual reduction in the level of premiums of compulsory third-party liability vehicle insurance in 2013.

In 2013, numerous summer floods were determinative in the non-life insurance business concerning claims costs. Unfortunately, the number of contracts decreased between 2012 and 2013 in the field of fire and damage to property insurance of individuals. Important progress was made in the area of consumer protection with the introduction of the MABISZ Premium Navigator that provides reliable comparison of compulsory third-party liability vehicle insurance premiums and annual cost ratios (MABISZ [2014] pp. 4-7.).

The negative trend in the insurance market ended in 2014. (See Figure 1.) The slow increase in the car sales market also contributed to this change. Sales in both the new car and used car markets increased, which, in turn, raised the number of insurance contracts.

The growth trend in the non-life insurance business continued in 2015. There was a significant increase in volume in the compulsory third-party liability vehicle insur-

HUNGARIAN STATISTICAL REVIEW, VOLUME 2, NuMBER 2, PP. 79-105. DOI: 10.35618/hsr2019.02.en079 
ance: compared with the number of contracts at the end of 2014, insurers managed more third-party liability vehicle insurance contracts at the end of 2015. This figure reflects a growth in the new car sales market, which is presented in Figure 3. Furthermore, the number of uninsured vehicles decreased in 2015 due to the effective control systems. Nevertheless, in 2015 the HUF 107 billion premium revenue of the non-life insurance sector was still below the total market cap of HUF 125 billion in 2009. The other main motor vehicle business line, Casco, also showed some growth: the number of contracts increased from 812,000 in 2014 to 821,000 in 2015. (MABISZ [2016] p. 5.)

Figure 3. Third-party liability vehicle insurance contracts, number of vehicles on the road at the end of the year, and number of new and used vehicles registered for the first time in Hungary

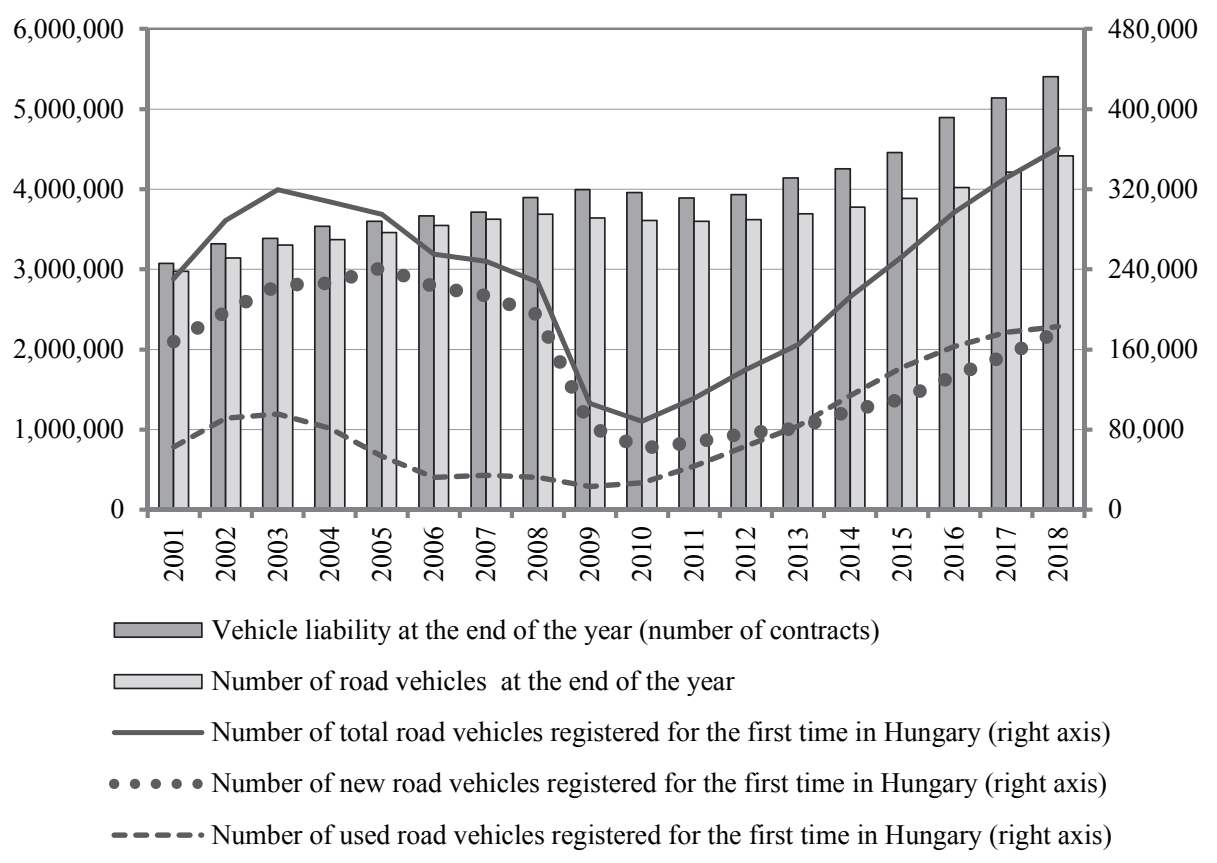

Source: Own calculation based on MNB and HCSO (Hungarian Central Statistical Office) data.

The non-life insurance business grew more dynamically in 2017 than the life insurance business, when comparing premium revenue. It can be contributed to the boom in liability vehicle insurance, which accounts for more than twice the industry average. However, compulsory third-party liability vehicle insurance fees started from a low baseline and are only now about to return to the pre-crisis level. Meanwhile, claim payments also increased dynamically, mainly due to the increase in

HuNGARIAN STATISTICAL REVIEW, VOLUME 2, NuMBER 2, PP. 79-105. DOI: 10.35618/hsr2019.02.en079 
parts and service charges, labour costs, and personal injury claims threatening the delicate premium-cost balance. Figure 4 shows that claims costs increased steeply in the period 2016-2018. (MABISZ [2018] pp. 6-7.)

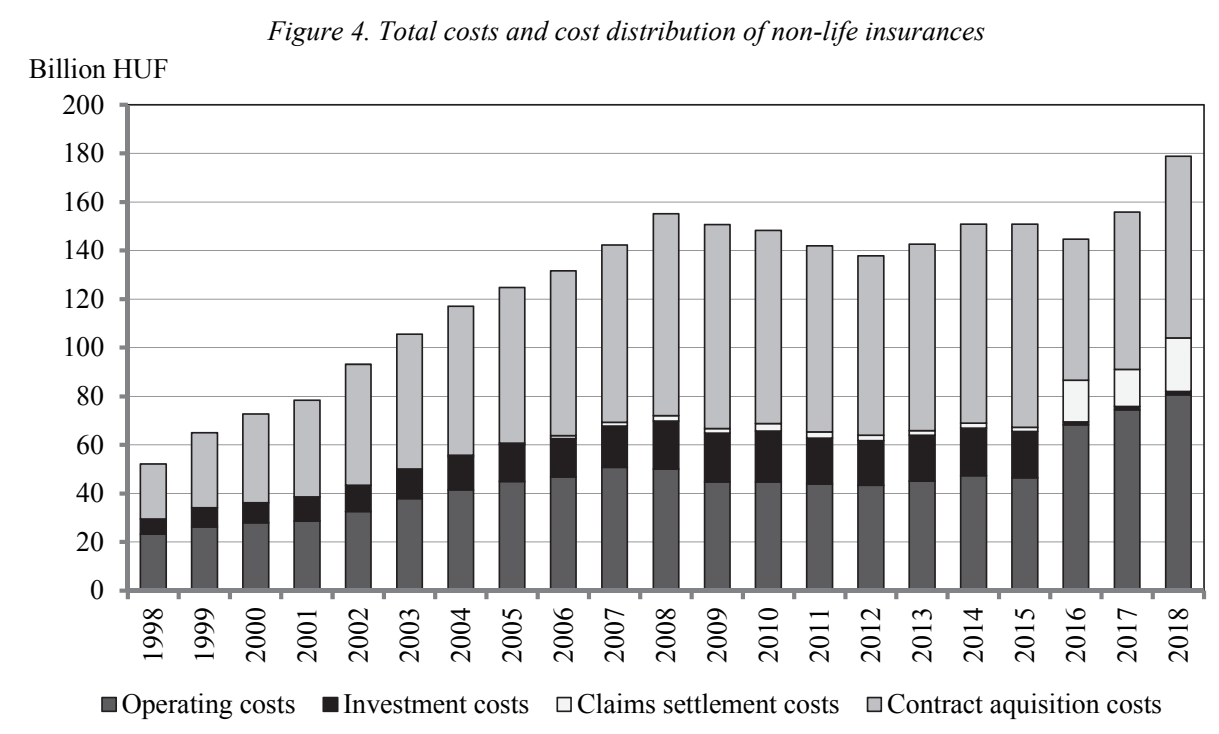

Source: Own calculation based on MNB data

\subsection{Calculation of gross value added by the insurance market according to ESA 2010}

According to ESA 2010, the output of insurance activities is calculated using different formulas for life, non-life, and reinsurance activities. Table 1 summarizes these calculation forms.

In the second row of the Table 1, 'the premiums supplements are the income earned from the investment of the insurance technical reserve of the insurers' (Official Journal of the European Union [2013] p. 386.). The adjusted claims incurred means the corrected amount of the claims. The adjustment eliminates 'the volatility in claims using historical data or accounting data on changes in the equalisation reserves' and in companies' own funds (Official Journal of the European Union [2013] p. 388.). In the case of reinsurance activities, accumulation should be avoided; therefore, the output is corrected by the commissions payable. In practice, the output is calculated using data from the annual reports of insurance companies.

HUNGARIAN STATISTICAL REVIEW, VOLUME 2, NUMBER 2, PP. 79-105. DOI: 10.35618/hsr2019.02.en079 
Table 1

Theoretical scheme for calculating the gross value added of insurance companies

\begin{tabular}{l|l|l}
\hline \multicolumn{1}{c|}{ Life insurance activities } & \multicolumn{1}{|c}{ Non-life insurance activities } & \multicolumn{1}{c}{ Reinsurance activities } \\
\hline + premiums earned & + premiums earned \\
+ premium supplements & + premium supplements \\
- benefits due & $\begin{array}{l}\text { + premiums earned } \\
+ \text { premium supplements } \\
\text { - increases (plus decreases) in technical } \\
\text { reserves and with-profits insurance }\end{array}$ & $\begin{array}{l}\text { - commissions payable } \\
\text { - adjusted claims incurred and } \\
\text { profit sharing }\end{array}$ \\
\hline
\end{tabular}

Source: Official Journal of the European Union [2013] 16.51, 16.52, 16.56. pp. 388-389.

The gross value added is calculated as the difference between output and intermediate consumption. The items are calculated separately for the life and non-life insurance businesses.

Table 2

Scheme for the calculation of gross value added by insurance companies

\begin{tabular}{|c|c|c|c|}
\hline \multicolumn{3}{|r|}{$\mathrm{P} .1=\mathrm{P} .11-\mathrm{P} .13+\mathrm{P} .14+\mathrm{P} .15+\mathrm{P} .16$} & Output for insurance companies and pension funds \\
\hline \multirow[t]{5}{*}{+} & \multicolumn{2}{|c|}{$\mathrm{P} .11=\mathrm{P} .111+\mathrm{P} .112-\mathrm{P} .113+\mathrm{P} .115$} & Insurance activity \\
\hline & + & P.111 & Premiums earned \\
\hline & + & P.112 & Adjusted premium supplements \\
\hline & - & P.113 & Claims due \\
\hline & + & P.115 & $\begin{array}{l}\text { Adjusted change in technical and actuarial } \\
\text { reserves }\end{array}$ \\
\hline- & \multicolumn{2}{|c|}{ P.13 } & Items adjusting sales to valuation to basic price \\
\hline+ & \multicolumn{2}{|c|}{ P.14 } & Own production capitalized \\
\hline+ & \multicolumn{2}{|c|}{ P.15 } & Imputed value of welfare services \\
\hline+ & \multicolumn{2}{|c|}{ P.16 } & $\begin{array}{l}\text { Imputed value of own produced services } \\
\text { provided to employee }\end{array}$ \\
\hline \multicolumn{3}{|c|}{ P.2 $=$ P.21 + P.22 + P.23 + P.24-P.26+P.27+P.28+P.29 } & Intermediate services \\
\hline+ & \multicolumn{2}{|c|}{ P.21 } & Material costs \\
\hline+ & \multicolumn{2}{|c|}{ P.22 } & Costs of contracted services \\
\hline+ & \multicolumn{2}{|c|}{ P.23 } & Costs of other services \\
\hline+ & \multicolumn{2}{|c|}{ P.24 } & Value of goods and services purchased for resale \\
\hline- & \multicolumn{2}{|c|}{ P.26 } & Expenses classified as wages and salaries in kind \\
\hline+ & \multicolumn{2}{|c|}{ P.27 } & Costs of small tools \\
\hline+ & \multicolumn{2}{|c|}{ P.28 } & Reinsurance balance \\
\hline+ & \multicolumn{2}{|c|}{ P.29 } & FISIM consumed \\
\hline \multicolumn{3}{|c|}{ B.1g = P.1 - P.2 } & Gross value added \\
\hline
\end{tabular}

Note. FISIM: financial intermediation services indirectly measured. In the table, the codes of ESA 2010 (Official Journal of European Union [2013]) are used.

Source: HCSO [2011].

HuNGARIAN STATISTICAL REVIEW, VOLUME 2, NuMBER 2, PP. 79-105. DOI: 10.35618/hsr2019.02.en079 
Based on the scheme presented in Table 2, the growth in insurance contracts has a linear relationship with gross value added. We argue that in the life insurance business, the cancellation rate and the contract acquisition costs might also have a significant impact on gross value added. Next, in Table 3, we show an example of how a change in unit-linked reserves affects gross value added. We chose unit-linked reserves because its share within total reserves increased at a high grade.

Table 3

Effect of change in the cancellation rate and contract acquisition costs on gross value added

\begin{tabular}{|c|c|c|c|c|c|}
\hline \multirow{2}{*}{$\begin{array}{l}\text { Sign taken into } \\
\text { account in the } \\
\text { calculation of } \\
\text { gross value } \\
\text { added }\end{array}$} & \multirow[t]{2}{*}{ Item } & $\begin{array}{l}\text { Decrease in } \\
\text { cancellation }\end{array}$ & $\begin{array}{l}\text { Increase in } \\
\text { cancellation }\end{array}$ & $\begin{array}{l}\text { Decrease in } \\
\text { contract acquisi- } \\
\text { tion costs }\end{array}$ & $\begin{array}{l}\text { Increase in } \\
\text { contract acquisi- } \\
\text { tion costs }\end{array}$ \\
\hline & & \multicolumn{4}{|c|}{ of unit-linked reserves } \\
\hline+ & P.111 Premiums earned & + & - & $(-)$ & $(+)$ \\
\hline+ & $\begin{array}{l}\text { P.112 Adjusted premium } \\
\text { supplements }\end{array}$ & + & - & + & - \\
\hline- & P.113 Claims due & + & - & $(-)$ & $(+)$ \\
\hline+ & $\begin{array}{l}\text { P.115 Adjusted change in } \\
\text { technical and actuarial } \\
\text { reserves }\end{array}$ & + & - & - & + \\
\hline \multirow[t]{2}{*}{-} & $\begin{array}{l}\text { P. } 22 \text { Costs of contracted } \\
\text { services }\end{array}$ & + & - & - & + \\
\hline & Gross value added & $-1+$ & $-1+$ & + & - \\
\hline
\end{tabular}

P.111 The earned premium increases when the unit-linked reserves' cancellation rate decreases because more premium income is expected. An increase in the cancellation rate results in a decrease in the premiums earned. A decrease in contract acquisition costs is expected to lead to a decrease in premiums earned; however, it is not directly proportional because it is highly dependent on sales channels and the agency network.

P.112 Adjusted premium supplements are affected in two directions. A decrease in the cancellation rate increases investment income (P.112) and as the ratio of unitlinked insurance within liabilities in the balance sheet increases, the P.1122 correction factor also increases. Conversely, an increase in the cancellation rate has the opposite effect. A decrease in contract acquisition costs will clearly increase the insurance company owner's income because contract acquisition costs should be deducted from the P.1121 item.

Decreasing cancellation rates can increase P.113, claims due, as more contractual clients retain their policy throughout the term of the contract, which increases the 
payment for an injury event with the same probability of death. This has a negative effect on gross value added. The reduction in contract acquisition costs has an indirect effect on claims due, presumably reducing them.

P.115 Adjusted changes in technical and actuarial reserves are as follows: A decrease in the cancellation rate increases the book value and market value of unitlinked insurance reserves, which has a negative effect on gross value added. Changes in contract acquisition costs have an impact on reserves in the same direction as the cancellation rate has. The item P.22 includes the fees for short-term contracts.

Changes in unit-linked reserves may decrease or increase gross value added in the event of a decrease (or increase) in the cancellation rate. However, the effect is unclear as it depends on the proportion of the increase (or decrease) in premium income and insurance company owner's income to the decrease (or increase) in technical and actuarial reserves. A decrease in contract acquisition costs, ceteris paribus, increases gross value added.

We, therefore, argue that in addition to premium income, the contract acquisition costs of unit-linked life insurance, the cancellation rate, and the expected return have an impact on gross value added.

\section{Data}

We collected time series data from Golden Books published by the Central Bank of Hungary (hereinafter MNB) for the years 2003-2017. Golden Books contain the individual accounting data of supervised institutions for each year, including the balance sheets and profit and loss statements for life insurance and non-life insurance companies. We also downloaded the yearbooks of MABISZ for the years 19912019. Using these two data sources, we compiled annual time series of premiums, claims costs, and operating costs at current prices. The main data are presented in Table A1 of the Appendix.

The database of the HCSO (Hungarian Central Statistical Office) contains data on the annual output and gross value added at current and previous prices of financial companies in the activities of insurance, reinsurance and pension funds according to NACE 65 Rev. 2. Using these data, we were able to calculate the intermediate consumption, the ratio of intermediate consumption to output, the volume index of gross value added, and the relevant implicit price indices. The time series for some of these data are presented in Table A2.

To prepare the econometric models, all data were calculated in volume terms. We performed a unit-root test (the Augmented-Dickey Fuller test with constant and trend), of which the results are presented in Table 4.

HUNGARIAN STATISTICAL REVIEW, VOLUME 2, NuMBER 2, PP. 79-105. DOI: 10.35618/hsr2019.02.en079 
Table 4

Results of the unit-root test

\begin{tabular}{l|l|c|c|c}
\hline \multicolumn{1}{c|}{ Variable } & lag & Test-statistic & Asymptotic $p$-value \\
\hline$y$ & Gross value added at constant price & 8 & -2.197270 & 0.49060 \\
\hline$x_{1}$ & Premiums at constant price & 5 & -3.128460 & 0.09957 \\
\hline$x_{2}$ & Claims costs at constant price & 5 & -1.247010 & 0.86800 \\
\hline$x_{3}$ & Operating costs at constant price & 4 & -2.193650 & 0.49260 \\
\hline$x_{4}$ & IC/output ratio & 8 & -0.444939 & 0.98600 \\
\hline
\end{tabular}

Note. Here and hereinafter, IC: intermediate consumption.

Based on the results of the unit-root test, all data were transformed into $d \log$ form to achieve stationarity. Our analyses were performed using EViews software.

\section{Methodology}

To test our hypothesis, we chose econometric modelling. The following linear equation model was written:

$$
y_{t}=c+\sum_{i=1}^{n} \beta_{i} x_{i t}+\varepsilon_{t},
$$

where $y_{t}$ is the $d \log$ value of gross value added at constant prices, $\beta_{i}$ is the parameter of the explanatory variable $x_{i t}$, and $\varepsilon_{t}$ is the error term.

Our analyses aimed to find an appropriate model to fit the data. We noted that our time series are very short as they are based on annual data. It is therefore not possible to test their predictive ability using ex-post forecasts; however, they provide evidence of which processes had an impact on gross value added in the past.

\section{Results}

According to Figure 5 that presents the development of premiums, claims costs, operating costs, and gross value added at constant prices, premiums and claims costs do not have strong relationships with gross value added.

HUNGARIAN STATISTICAL REVIEW, VOLUME 2, NuMBER 2, PP. 79-105. DOI: 10.35618/hsr2019.02.en079 
Figure 5. Premiums, claims costs, operating costs, and gross value added at average prices of 2005 Million HUF

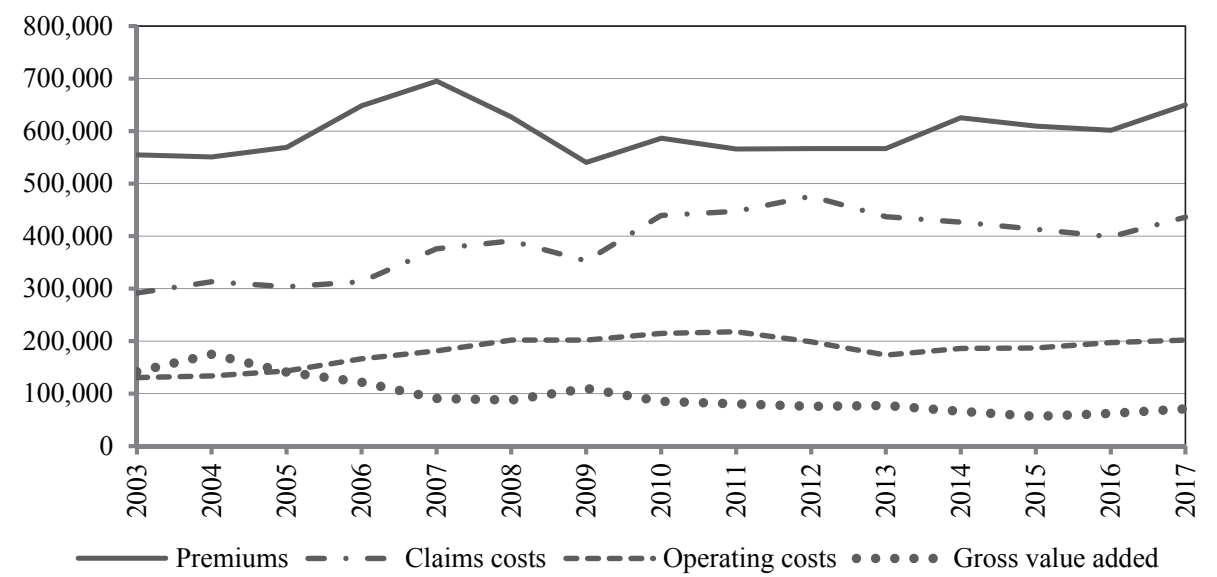

Source: Own calculation based on MNB and HCSO data.

In Figure 6, we present the total costs, output, intermediate consumption, gross value added, and the ratio of intermediate consumption to output of the insurance industry at current prices. The ratio of intermediate consumption to output changed from $55 \%$ in 1998 to $78 \%$ in 2018, which determined the movement of gross value added.

Figure 6. Total costs, output, intermediate consumption, gross value added, and the ratio of intermediate consumption to output ratio of the insurance industry, at current prices

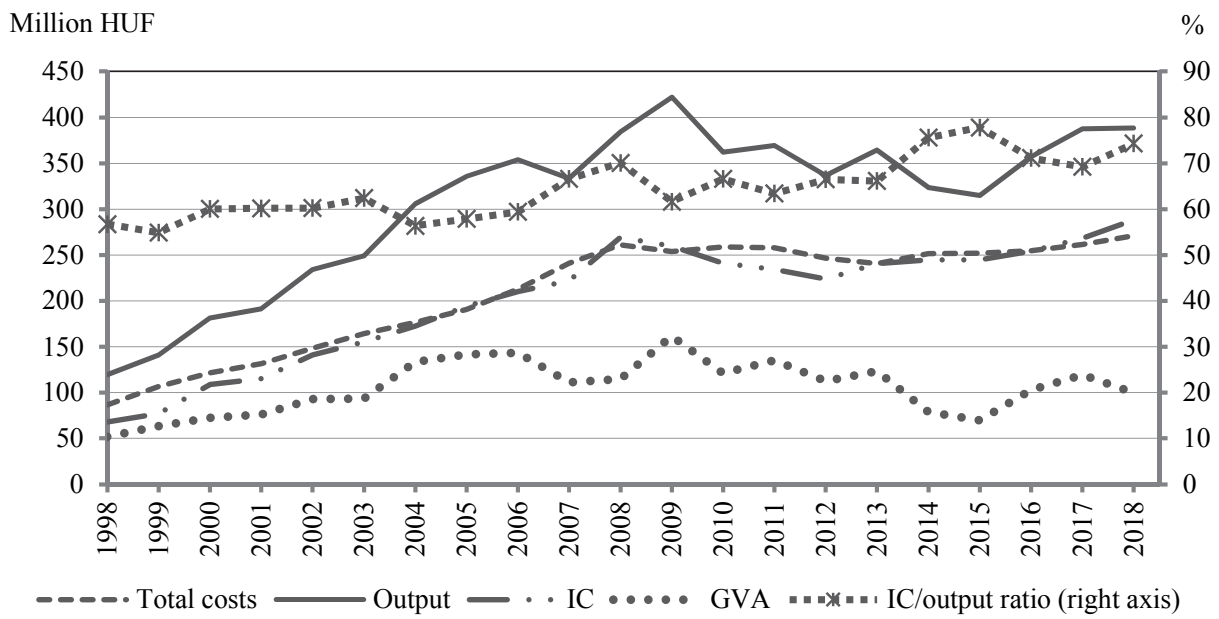

Note. GVA: gross value added.

Source: Own calculation based on MNB and HCSO data.

HUNGARIAN STATISTICAL REVIEW, VOLUME 2, NUMBER 2, PP. 79-105. DOI: 10.35618/hsr2019.02.en079 
Figure 7 shows that the total costs of insurance companies increased from 1998 to 2008 in nominal values, after which they stagnated during the period 2008-2011. Then, after a slight decrease, it started to increase again from 2014. Between 2016 and 2018, the distribution of cost items changed significantly.

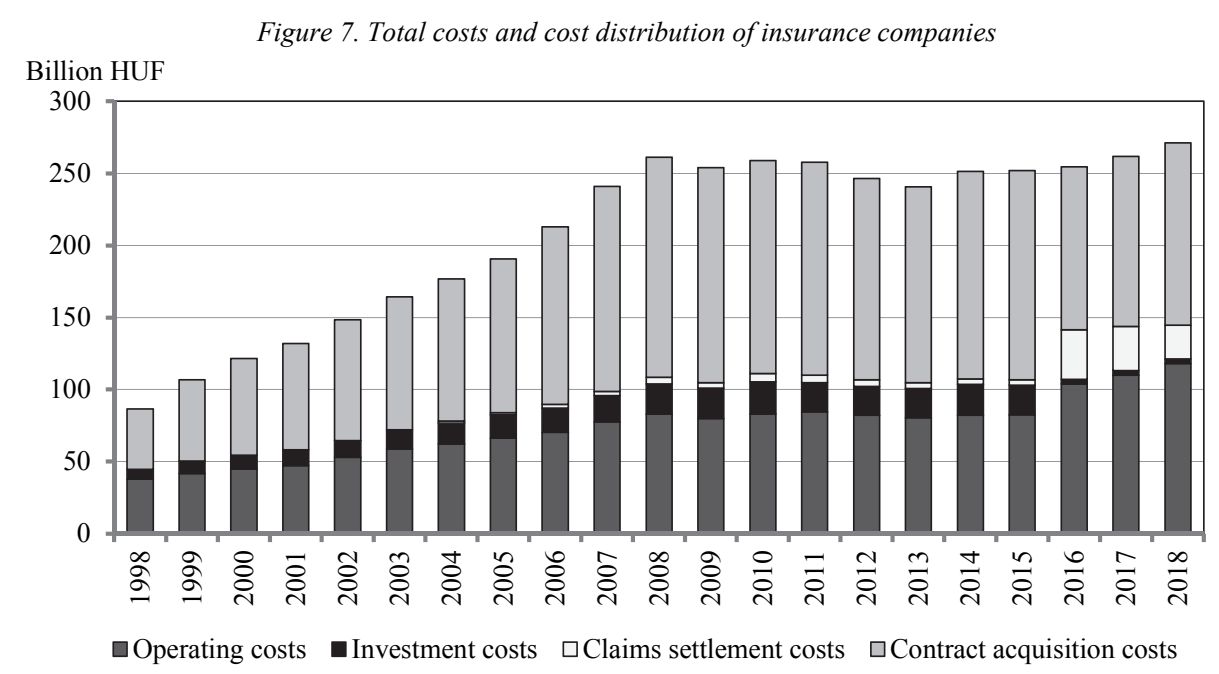

Source: Own calculation based on MNB data

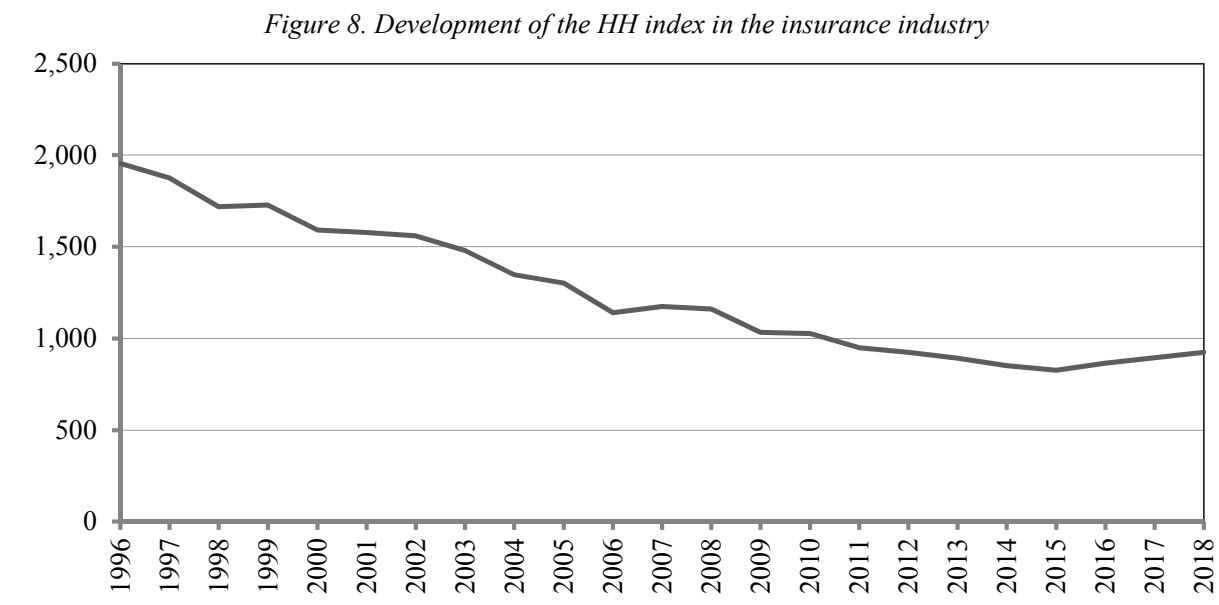

Source: Own calculation based on MABISZ [1999-2019] data.

We analysed the market concentration using the HH (Herfindahl-Hirschman) index. Figure 8 shows that the HH index continuously decreased from 1996 to 2015.

HUNGARIAN STATISTICAL REVIEW, VOLUME 2, NuMBER 2, PP. 79-105. DOI: 10.35618/hsr2019.02.en079 
It is closely related to the liberalisation of the industry market. From 2016, the $\mathrm{HH}$ index started to increase again, which may indicate that insurance companies were trying to achieve appropriate economies of scale.

As it was mentioned, the aim of this study was to create a model that fits past data; therefore, the process of model construction is presented step by step below.

\subsection{Analysis of 'premiums' as an explanatory variable}

First, we fitted the model with premiums as the explanatory variable for the total sample period and then for several sub-periods using the 'rolling window' method. We found that this explanatory variable is significant in the 2007-2016 sample (see Tables 5 and 6); however, it is not significant for the total sample.

Table 5

Results of Model 1 (2007-2016 sample)

\begin{tabular}{l|c|c|c|c}
\hline \multicolumn{1}{c|}{ Name of variable } & Symbol of variable & Parameter & $t$-statistic & $p$-value \\
\hline Constant & $c$ & -0.078354 & -2.384919 & 0.0442 \\
\hline Premiums & $x_{1}$ & -1.579738 & -3.593085 & 0.0071 \\
\hline
\end{tabular}

Table 6

\begin{tabular}{l|c|l|c}
\multicolumn{5}{c}{ Performance of Model 1 (2007-2016 sample) } \\
\hline \multicolumn{1}{c|}{ Statistical indicator } & Value & \multicolumn{1}{c}{ Statistical indicator } & Value \\
\hline$R^{2}$ & 0.617413 & Mean of the dependent variable & -0.066631 \\
\hline Adjusted $R^{2}$ & 0.569589 & Standard deviation of the dependent variable & 0.157577 \\
\hline Standard error of regression & 0.103379 & Akaike information criterion & -1.523964 \\
\hline Sum of squared residuals & 0.085499 & Schwarz criterion & -1.463447 \\
\hline Log likelihood & 9.619821 & Hannan-Quinn criterion & -1.590351 \\
\hline$F$-statistic & 12.910260 & Durbin-Watson statistic & 1.947715 \\
\hline Probability of $F$-statistic & 0.007053 & & \\
\hline
\end{tabular}

\subsection{Analysis of 'claims costs' as an explanatory variable}

The claims costs variable was tested in a linear equation, first using the total sample period and then using the 'rolling window' method in several sub-periods. We discovered that this variable is significant in the period 2005-2013.

HuNGARIAN STATISTICAL REVIEW, VOLUME 2, NuMBER 2, PP. 79-105. DOI: 10.35618/hsr2019.02.en079 
Results of Model 2 (2005-2013 sample)

\begin{tabular}{l|c|c|c|c}
\hline \multicolumn{1}{c|}{ Name of variable } & Symbol of variable & Parameter & $t$-statistic & $p$-value \\
\hline Constant & $c$ & -0.0137489 & -0.5110 & 0.6906 \\
\hline Claims costs & $x_{2}$ & -1.1522430 & -5.4408 & 0.0010 \\
\hline
\end{tabular}

Table 8

Performance of Model 2 (2005-2013 sample)

\begin{tabular}{l|c|l|r}
\hline \multicolumn{1}{c|}{ Statistical indicator } & \multicolumn{1}{c|}{ Value } & \multicolumn{1}{c}{ Statistical indicator } & Value \\
\hline$R^{2}$ & 0.808757 & Mean of the dependent variable & -0.090076 \\
\hline Adjusted $R^{2}$ & 0.781437 & Standard deviation of the dependent variable & 0.159918 \\
\hline Standard error of regression & 0.074763 & Akaike information criterion & -2.155857 \\
\hline Sum of squared residuals & 0.039127 & Schwarz criterion & -2.112029 \\
\hline Log likelihood & 11.701360 & Hannan-Quinn criterion & -2.250437 \\
\hline$F$-statistic & 29.602730 & Durbin-Watson statistic & 1.766369 \\
\hline Probability of $F$-statistic & 0.000965 & & \\
\hline
\end{tabular}

\subsection{Analysis of 'operating costs' as an explanatory variable}

As a third possible explanatory variable, we tested operating costs in a linear equation. The results showed that this variable is not significant for the total period but only for the sub-period 2004-2013.

Results of Model 3 (2004-2013 sample)

\begin{tabular}{l|c|c|c|c}
\hline \multicolumn{1}{c|}{ Name of variable } & Symbol of variable & Parameter & $t$-statistic & $p$-value \\
\hline Constant & $c$ & -0.011813 & -0.270256 & 0.7938 \\
\hline Operating costs & $x_{3}$ & -1.965457 & -3.041720 & 0.0160 \\
\hline
\end{tabular}


Performance of Model 3 (2004-2013 sample)

\begin{tabular}{l|c|l|r}
\hline \multicolumn{1}{c|}{ Statistical indicator } & \multicolumn{1}{|c|}{ Value } & \multicolumn{1}{c}{ Statistical indicator } & Value \\
\hline$R^{2}$ & 0.536287 & Mean of the dependent variable & -0.059907 \\
\hline Adjusted $R^{2}$ & 0.478323 & Standard deviation of the dependent variable & 0.178422 \\
\hline Standard error of regression & 0.128869 & Akaike information criterion & -1.083185 \\
\hline Sum of squared residuals & 0.132858 & Schwarz criterion & -1.022668 \\
\hline Log likelihood & 7.415927 & Hannan-Quinn criterion & -1.149572 \\
\hline$F$-statistic & 9.252059 & Durbin-Watson statistic & 2.425791 \\
\hline Probability of $F$-statistic & 0.016021 & & \\
\hline & & &
\end{tabular}

\subsection{Analysis of the relationships among the variables 'premiums', 'claims costs', and 'operating costs'}

Next, we aimed to determine the correlations among the variables premiums, claims costs, and operating costs. (See Table 11.)

Correlations among variables

\begin{tabular}{l|c|c|c}
\hline \multicolumn{1}{c|}{ Correlation } & $d \log$ (premiums) & $d \log$ (claims costs) & $d \log$ (operating costs) \\
\hline$d \log$ (premiums) & 1.00 & & \\
\hline$d \log$ (claims costs) & $0.69(0.0056)$ & 1.00 & \\
\hline$d \log$ (operating costs) & $0.46(0.0927)$ & $0.56(0.0357)$ & 1.00 \\
\hline
\end{tabular}

Note. See probability of $t$-statistic in brackets.

The correlation between premiums and claims costs is stronger than average, which causes multicollinearity between the variables. This means that only one variable in the model will be significant and the others should be discarded.

\subsection{Analysis of the 'ratio of intermediate consumption to output' as an explanatory variable}

Based on Figure 6, we used the ratio of intermediate consumption to output as an explanatory variable in the model, first for the period 1997-2017 (see Tables 12 and 13) and then for the sub-period 2006-2017 (see Tables 14 and 15). 
Results of Model 4 (1997-2017 sample)

\begin{tabular}{l|c|c|c|c}
\hline \multicolumn{1}{c|}{ Name of variable } & Symbol of variable & Parameter & $t$-statistic & $p$-value \\
\hline Constant & $c$ & 0.02215 & -1.708 & 0.1040 \\
\hline IC/output ratio & $x_{4}$ & -1.20056 & -4.789 & 0.0001 \\
\hline
\end{tabular}

Performance of Model 4 (1997-2017 sample)

\begin{tabular}{l|r|l|r}
\hline \multicolumn{1}{c|}{ Statistical indicator } & \multicolumn{1}{c|}{ Value } & \multicolumn{1}{c}{ Statistical indicator } & Value \\
\hline$R^{2}$ & 0.546864 & Mean of the dependent variable & -0.052188 \\
\hline Adjusted $R^{2}$ & 0.523015 & Standard deviation of the dependent variable & 0.145645 \\
\hline Standard error of regression & 0.100588 & Akaike information criterion & -34.968610 \\
\hline Sum of squared residuals & 0.192242 & Schwarz criterion & -32.879560 \\
\hline Log likelihood & 19.484300 & Hannan-Quinn criterion & -34.515230 \\
\hline$F$-statistic & 22.930020 & Durbin-Watson statistic & 1.856888 \\
\hline Probability of $F$-statistic & 0.000128 & & \\
\hline
\end{tabular}

We found that the ratio of intermediate consumption to output is a significant explanatory variable, both in the total period and in the sub-period 2006-2017.

We also tested the heteroscedasticity of the model using the Breusch-PaganGodfrey test. The null hypothesis of this test is the homoscedasticity of the examined model. According to the test statistics (LM [Lagrange multiplier test statistic]: 0.299468 ; probability $\chi^{2}(1): 0.584216$, where the degree of freedom is 1 ; explained sum of squares: 0.598937 ) and the $p$-value, we accept the null hypothesis that our model is homoscedastic.

As shown in Tables 6 and 8, premiums and claims costs are good proxies for gross value added in the periods 2007-2016 and 2005-2013, but they were unable to capture the pattern of gross value added for the total period. This means that the movement in gross value added of insurance activity was influenced by the change in the ratio of intermediate consumption to output. According to Table 13,52.3\% of the variance of gross value added by insurance, reinsurance, and pension funds according to NACE 65 Rev. 2 was explained by the ratio of intermediate consumption to output in the period 1997-2017. This percentage is $72 \%$ for the sub-period 2006-2017. (See Table 15.) 
Results of Model 5 (2006-2017 sample)

\begin{tabular}{l|c|c|c|c}
\hline \multicolumn{1}{c|}{ Name of variable } & Symbol of variable & Parameter & $t$-statistic & $p$-value \\
\hline Constant & $c$ & -0.03201 & -1.325 & 0.2146 \\
\hline IC/output ratio & $x_{4}$ & -1.69983 & -5.406 & 0.0003 \\
\hline
\end{tabular}

Performance of Model 5 (2006-2017 sample)

\begin{tabular}{l|r|l|r}
\hline \multicolumn{1}{c|}{ Statistical indicator } & \multicolumn{1}{c|}{ Value } & \multicolumn{1}{c}{ Statistical indicator } & \multicolumn{1}{c}{ Value } \\
\hline$R^{2}$ & 0.745041 & Mean of the dependent variable & -0.057382 \\
\hline Adjusted $R^{2}$ & 0.719546 & Standard deviation of the dependent variable & 0.154967 \\
\hline Standard error of regression & 0.082068 & Akaike information criterion & -24.138450 \\
\hline Sum of squared residuals & 0.067350 & Schwarz criterion & -23.168630 \\
\hline Log likelihood & 14.069220 & Hannan-Quinn criterion & -24.497510 \\
\hline$F$-statistic & 29.222050 & Durbin-Watson statistic & 1.689000 \\
\hline Probability of $F$-statistic & 0.000299 & & \\
& & & \\
\hline
\end{tabular}

\section{Conclusions}

In recent years, many changes have occurred in the Hungarian insurance industry. In this study, we examined these changes and tried to find answer to the question whether premiums and claims costs are good proxies to capture the pattern of insurance companies' gross value added during the period 2003-2017. Using time series analysis, we studied the relationship between total annual gross value added and the aggregated accounting data of Hungarian insurance companies. We have found that premiums and claims costs are good proxies for gross value added only in certain sub-periods. According to the results, the ratio of intermediate consumption to output varied across a relatively wide range, which had a great impact on gross value added by the insurance business. Because this ratio is determined by several factors - such as premiums, claims costs, changes in technical and actuarial reserves, and cost of contracted services -, each of these factors separately is not a good proxy for the long term; however, in the short term, they might be suitable. 


\section{Appendix}

Table A1

Premiums, claim and operating costs of life insurance and non-life insurance companies (million HUF at current prices)

\begin{tabular}{|c|c|c|c|}
\hline Year & Premium & Claims cost & Operating cost \\
\hline 2001 & 366,318 & 188,076 & \\
\hline 2002 & 494,589 & 205,250 & \\
\hline 2003 & 458,817 & 240,936 & 137,705 \\
\hline 2004 & 480,013 & 272,864 & 132,370 \\
\hline 2005 & 569,685 & 303,691 & 151,024 \\
\hline 2006 & 705,082 & 340,845 & 172,712 \\
\hline 2007 & 803,873 & 434,730 & 195,901 \\
\hline 2008 & 774,175 & 482,779 & 215,935 \\
\hline 2009 & 693,787 & 452,765 & 200,922 \\
\hline 2010 & 708,026 & 530,548 & 199,356 \\
\hline 2011 & 679,629 & 537,240 & 199,498 \\
\hline 2012 & 633,683 & 532,030 & 190,030 \\
\hline 2013 & 680,833 & 525,150 & 187,832 \\
\hline 2014 & 712,240 & 486,216 & 192,760 \\
\hline 2015 & 710,189 & 481,490 & 191,080 \\
\hline 2016 & 749,877 & 496,934 & 194,981 \\
\hline 2017 & 817,206 & 548,652 & 203,134 \\
\hline
\end{tabular}

Source: $M N B$ [2003-2017]. 


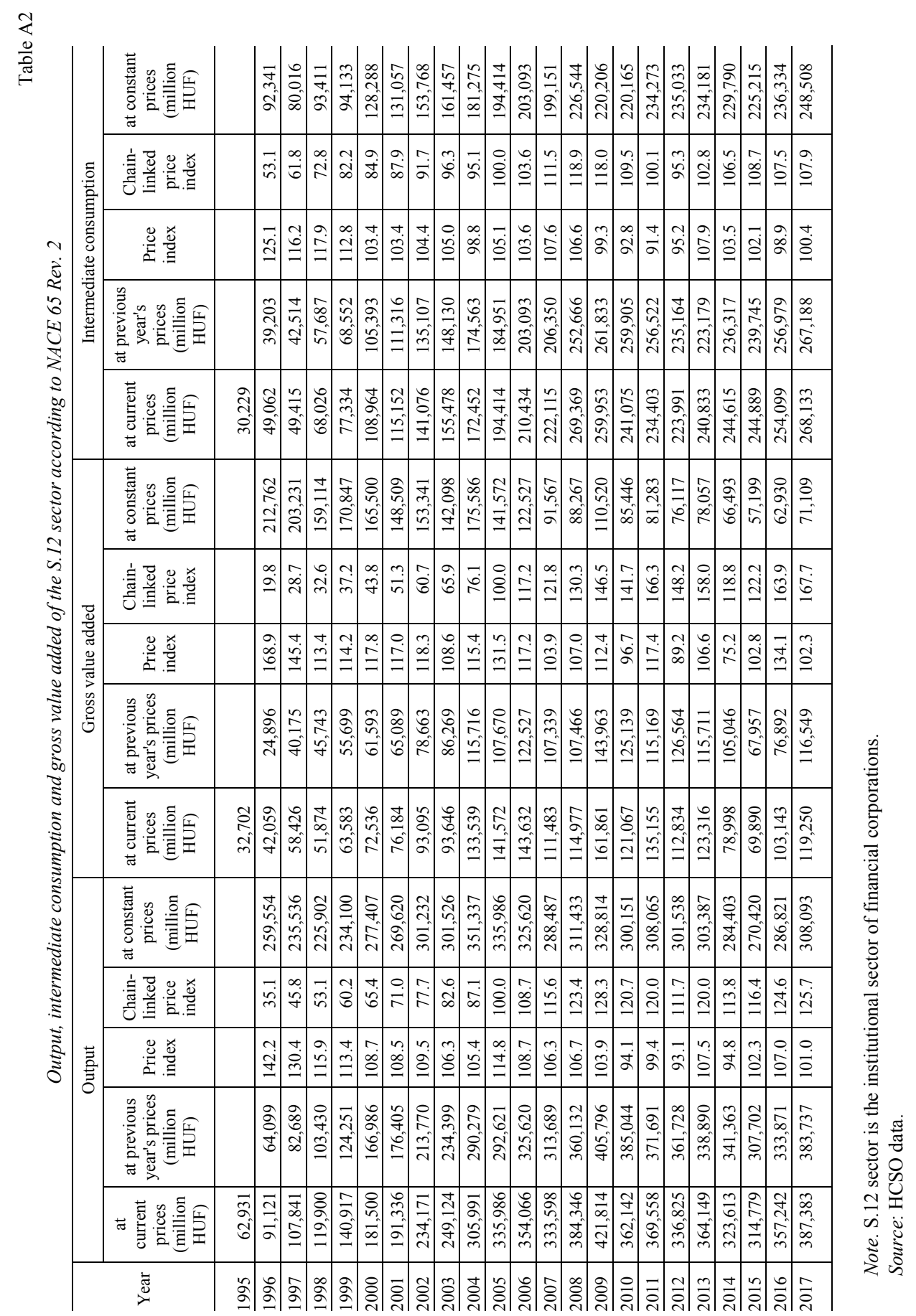




\section{References}

Avram, K. - Nguyen, Y. - Skully, M. [2010]: Insurance and Economic Growth: A Cross Country Examination. Monash University, Department of Accounting and Finance. Caulfield.

BurgESS, S. [2011]: Measuring Financial Sector Output and Its Contribution to UK GDP. Bank of England Quarterly Bulletin 2011Q3. Bank of England. London. https:/www.bankofengland.co.uk/quarterly-bulletin/2011/q3/measuring-financial-sectoroutput-and-its-contribution-to-uk-gdp

COMMISSION OF THE EC (EUROPEAN COMMUNITIES) - IMF (INTERNATIONAL MONETARY Fund) OECD (ORGANIZATION FOR ECONOMIC CO-OPERATION AND DEVELOPMENT) - UN (UNITED NATIONS) - WoRLD BANK [1993]: System of National Accounts 1993. Brussels/Luxembourg, New York, Paris, Washington, D.C. https://unstats.un.org/unsd/nationalaccount/docs/ 1993sna.pdf

ELING, M. - LuHNEN, M. [2008]: Understanding price competition in the German motor insurance market. Zeitschrift für die gesamte Versicherungswissenschaft. Vol. 97. Supplement 1. pp. 37-50. https://doi.org/10.1007/s12297-008-0027-5

EuROSTAT [2013]: European System of Accounts 2010. Publications Office of the European Union. Luxembourg. https://doi.org/10.2785/16644

Focarelli, D. - Pozzolo, A. F. [2008]: Cross-border M\&As in the financial sector: Is banking different from insurance? Journal of Banking \& Finance. Vol. 32. Issue 1. pp. 15-29. https://doi.org/10.1016/j.jbankfin.2007.09.002

HAISS, P. - SÜMEGI, K. [2008]: The relationship between insurance and economic growth in Europe: a theoretical and empirical analysis. Empirica. Vol. 35. No. 4. pp. 405-431. https://doi.org/10.1007/s10663-008-9075-2

HCSO (Hungarian Central Statistical Office) [2011]: GNI Inventory of Hungary, Version 2.2. Budapest. https://www.ksh.hu/docs/eng/xftp/modsz/gni_inventory_ver_2_2.pdf

MAHLBERG, B - URL, T. [2010]: Single market effects on productivity in the German insurance industry. Journal of Banking \& Finance. Vol. 34. Issue 7. pp. 1540-1548. https://doi.org/10.1016/j.jbankfin.2009.09.05

Triplett, J. E. - Bosworth, B. P. [2004]: Price, Output, and Productivity of Insurance: Conceptual Issues. SSHR Conference on Index Number Theory and the Measurement of Prices and Productivity. Vancouver, B.C. 30 June - 3 July. http://www.ipeer.ca/papers/ Triplett\&Bosworth,May26,2004.pdf

United Nations Statistics Division [1968]: System of National Accounts 1968. Studies in Methods. Series F. No. 2. Rev. 3. New York. https://unstats.un.org/unsd/nationalaccount/ docs/1968SNA.pdf

\section{Internet references}

Act CXVII of 1995 on personal income tax. https:/www.lexadin.nl/wlg/legis/nofr/eur/ arch/hun/cxvii1995.pdf

HUNGARIAN STATISTICAL REVIEW, VOLUME 2, NUMBER 2, PP. 79-105. DOI: 10.35618/hsr2019.02.en079 
Decree No. 21/2011. (VI. 10.) NGM of the Minister for National Economy on the bonus-malus system and being rated in it, and on the rules for issuing loss history certificates. https://net.jogtar.hu/jogszabaly?docid=a1 100021.ngm\&dbnum=533\&getdoc $=1$

Eurostat [2008]: NACE Rev. 2 Statistical Classification of Economic Activities in the European Community. Office for Official Publications of the European Communities. Luxembourg. https://ec.europa.eu/eurostat/documents/3859598/5902521/KS-RA-07-015-EN.PDF

HCSO: Dissemination database http://statinfo.ksh.hu/Statinfo/themeSelector.jsp?\&lang=en

MABISZ (AsSOCIATION OF Hungarian InSURANCE COMPANIES) [1999]: Yearbook of Hungarian Insurers 1999. Budapest. https://mabisz.hu/wp-content/uploads/2018/08/evkonyv-1999magyar.pdf

MABISZ [2000]: Yearbook of Hungarian Insurers 2000. Budapest. https://mabisz.hu/wpcontent/uploads/2018/08/evkonyv-2000-magyar.pdf

MABISZ [2001]: Yearbook of Hungarian Insurers 2001. Budapest. https://mabisz.hu/wpcontent/uploads/2018/08/evkonyv-2001-magyar.pdf

MABISZ [2002]: Yearbook of Hungarian Insurers 2002. Budapest. https://mabisz.hu/wpcontent/uploads/2018/08/yearbook-2002-english.pdf

MABISZ [2003]: Yearbook of Hungarian Insurers 2003. Budapest. https://mabisz.hu/wpcontent/uploads/2018/08/yearbook-2003-english.pdf

MABISZ [2004]: Yearbook of Hungarian Insurers 2004. Budapest. https://mabisz.hu/wpcontent/uploads/2018/08/yearbook-2004-english.pdf

MABISZ [2005]: Yearbook of Hungarian Insurers 2005. Budapest. https://mabisz.hu/wpcontent/uploads/2018/08/yearbook-2005-english.pdf

MABISZ [2006]: Yearbook of Hungarian Insurers 2006. Budapest. https://mabisz.hu/wpcontent/uploads/2018/08/yearbook-2006-english.pdf

MABISZ [2007]: Yearbook of Hungarian Insurers 2007. Budapest. https://mabisz.hu/wpcontent/uploads/2018/08/yearbook-2007-english.pdf

MABISZ [2008]: Yearbook of Hungarian Insurers 2008. Budapest. https://mabisz.hu/wpcontent/uploads/2018/08/yearbook-2008-english.pdf

MABISZ [2009]: Yearbook of Hungarian Insurers 2009. Budapest. https://mabisz.hu/wpcontent/uploads/2018/08/yearbook-2009-english.pdf

MABISZ [2010]: Yearbook of Hungarian Insurers 2010. Budapest. https://mabisz.hu/wpcontent/uploads/2018/08/yearbook-2010-english.pdf

MABISZ [2011]: Yearbook of Hungarian Insurers 2011. Budapest. https://mabisz.hu/wpcontent/uploads/2018/08/yearbook-2011-english.pdf

MABISZ [2012]: Yearbook of Hungarian Insurers 2012. Budapest. https://mabisz.hu/wpcontent/uploads/2018/08/yearbook-2012-english.pdf

MABISZ [2013]: Yearbook of Hungarian Insurers 2013. Budapest. https://mabisz.hu/wpcontent/uploads/2018/08/yearbook-2013-english.pdf

MABISZ [2014]: Yearbook of Hungarian Insurers 2014. Budapest. https://mabisz.hu/wpcontent/uploads/2018/08/yearbook-2014-english.pdf

MABISZ [2015]: Yearbook of Hungarian Insurers 2015. Budapest. https://mabisz.hu/wpcontent/uploads/2018/08/yearbook-2015-english.pdf 
MABISZ [2016]: Yearbook of Hungarian Insurers 2016. Budapest. https://mabisz.hu/wpcontent/uploads/2018/08/yearbook-2016-english.pdf

MABISZ [2017]: Yearbook of Hungarian Insurers 2017. Budapest. https://mabisz.hu/wpcontent/uploads/2018/08/yearbook-2017-english.pdf

MABISZ [2018]: Yearbook of Hungarian Insurers 2018. Budapest. https://mabisz.hu/wpcontent/uploads/2018/11/mabisz-e\%CC\%81vko\%CC\%88nyv-2019-v10-EN.pdf

MABISZ [2019]: Yearbook of Hungarian Insurers 2019. Budapest. https://mabisz.hu/wpcontent/uploads/2018/11/mabisz-e\%CC\%81vko\%CC\%88nyv-2019-EN-2.pdf

MAGYAR KÖZLÖNY [2000]: 2000. évi C. törvény a számvitelröl. No. 95. 21 September. pp. 5790-5867.

MAGYAR KÖZLÖNY [2003]: 2003. évi LX. törvény a biztositókról és a biztositási tevékenységröl. No. 84. 15 July. pp. 6712-6787.

MAGYAR KÖZLÖNY [2004]: 192/2000. (XI. 24.) Korm. r. a biztositók éves beszámoló készitési és könyvvezetési kötelezettségének sajátosságairól. No. 114. 24 November. pp. 7161-7174.

MAGYAR KÖZLÖNY [2009a]: 2009. évi CXVI. törvény az egyéni vállalkozóról és az egyéni cégröl szóló 2009. évi CXV. törvénnyel és a megtakaritások ösztönzésével összefüggö törvénymódositásokról. No. 161. 16 November. pp. 40163-40213.

MagYar KÖZlönY [2009b]: 2009. évi CXX. törvény a Polgári Törvénykönyvröl. No. 165. 20 November. pp. 41986-42214.

MAGYAR KÖZLÖNY [2009c]: 2009. évi LXII. törvény a kötelezö gépjármü-felelösségbiztositásról. No. 89. 29 June. pp. 22806-22826.

MNB (Magyar Nemzeti Bank [The Central Bank of Hungary]) [2003-2017]: Golden Books. https://www.mnb.hu/en/supervision/time-series/golden-books

OfFicial Journal of THE EUROPEAN Union [2013]: Regulation (EU) No 549/2013 of the European Parliament and of the Council of 21 May 2013 on the European system of national and regional accounts in the European Union. Vol. 56. L 174.26 June. pp. 1-727. https://eur-lex.europa.eu/legal-content/EN/TXT/PDF/?uri=CELEX:32013R0549\&from=EN 